\title{
Circumpolar connections between Antarctic krill (Euphausia superba Dana) populations: investigating the roles of ocean and sea ice transport
}

\author{
S. E. Thorpe * , E. J. Murphy and J. L. Watkins \\ British Antarctic Survey, Natural Environment Research Council, High Cross, Madingley \\ Road, Cambridge, CB3 OET, UK
}

\begin{abstract}
Antarctic krill, Euphausia superba Dana, has a heterogeneous circumpolar distribution in the Southern Ocean. Krill have a close association with sea ice which provides access to a critical food source and shelter, particularly in the early life stages. Advective modelling of transport pathways of krill have until now been on regional scales and have not taken explicit account of sea ice. Here we present Lagrangian modelling studies at the circumpolar scale that include interaction with sea ice. The advection scheme uses ocean velocity output from the Ocean Circulation and Climate Advanced Modelling project (OCCAM) model together with satellite-derived sea ice motion vectors to examine the potential roles of the ocean and sea ice in maintaining the observed circumpolar krill distribution. We show that the Antarctic Coastal Current is likely to be important in generating the large-scale distribution and that sea ice motion can substantially modify the ocean transport pathways, enhancing retention or dispersal depending upon location. Within the major krill region of the Scotia Sea, the effect of temporal variability in both the ocean and sea ice velocity fields is examined. Variability in sea ice motion increases variability of influx to South Georgia, at times concentrating the influx into pulses of arrival. This variability has implications for the ecosystem around the island. The inclusion of sea ice motion leads to the identification
\end{abstract}


of source regions for the South Georgia krill populations additional to those identified when only ocean motion is considered. This study indicates that the circumpolar oceanic circulation and interaction with sea ice is important in determining the large-scale distribution of krill and its associated variability.

Key words: Antarctic krill, ecosystems, ocean circulation, sea ice, life cycle, variability, Southern Ocean

\section{Introduction}

Zooplankton are major grazers of phytoplankton and have an important role in determining the fate of carbon fi xed in the upper ocean (Banse, 1995). Models of the dynamics of ocean ecosystems are being developed to examine the controls on upper ocean carbon budgets (e.g. Steinberg et al., 2001). However, within ocean ecosystem models developed for analysing carbon budgets, zooplankton are often represented as single compartments with no structure based on the model of Fasham et al. (1990). This may be suffi cient to represent small, fast growing microzooplankton (e.g. Popova et al., 2002), but is not a realistic representation for zooplankton that have complex life cycles, live 1,2 or more years and may undergo vertical migrations of over $1000 \mathrm{~m}$ and horizontal movements of over $1000 \mathrm{~km}$. For such species more complex models are required that consider the changes in biological-physical process interactions during development. For some of the well-studied zooplankton species of the North Atlantic detailed models of the life cycles are being developed. For example, population models of Calanus finmarchicus are being coupled with general circulation models to examine the biological-physical interactions during their life cycle (Zakardjian et al., 2003; Heath et al., 2004; Speirs et al., 2005). Developing more realistic models for other ocean ecosystems that include the life-cycles of key zooplankton species and their interactions with the physical environment is a key goal of global ocean ecosystem research.

\footnotetext{
* Corresponding author.

Email address: seth@bas.ac.uk (S. E. Thorpe).
} 
In the Southern Ocean, Antarctic krill (Euphausia superba Dana) is a key species in the food web being a major grazer of phytoplankton (Atkinson et al., 2001) and a major prey item of many of the seal and seabird species that occur in such large numbers in the region (Croxall et al., 1988). However, krill are not homogeneously distributed in the Southern Ocean and occur in much higher densities across the Scotia Sea and around the continent than in other open ocean regions (Marr, 1962; Atkinson et al., 2004; Siegel, 2005, Fig. 1). Within these regions the distribution and abundance of krill show marked seasonal and interannual variation (e.g. Brierley et al., 1997; Loeb et al., 1997; Siegel et al., 1998), and although there are detailed studies of local dynamics (Murphy et al., 1998, 2004a), there is limited understanding of the factors controlling their distribution in oceanic regions. Krill grow to approximately $15 \mathrm{~mm}$ in length before their fi rst winter (see Fig. 1 of Hofmann and Lascara, 2000) and do not mature until they are at least 2 years old (Cuzin-Roudy, 1987a,b; Siegel and Loeb, 1994), during which time they will have overwintered twice. During the early summer periods the juvenile krill will be transported in the ocean currents as largely passive particles. Larger, adult krill are more mobile and swimming will become more important as they can maintain speeds of $10-15 \mathrm{~cm} \mathrm{~s}^{-1}$ (Kils, 1982). However, in oceanic regions the ocean current fbws are likely to dominate their distribution during summer. A number of fi eld and modelling studies have examined the role of advection by ocean currents in the distribution of Antarctic krill (Hofmann et al., 1998; Murphy et al., 1998, 2004a,b; Fach et al., 2002, 2006; Thorpe et al., 2002, 2004; Fach and Klinck, 2006). The modelling work has focussed on the summer period in the Scotia Sea and has shown that ocean currents can connect krill populations at the regional scale.

However, ocean circulation is not the only physical factor that can affect distribution of Antarctic krill. Sea ice is a key overwintering habitat for krill providing both access to a vital food source and refuge from predators. Observations of larval and juvenile krill in close association with sea ice, both feeding on algae on its undersurface and taking refuge in channels within the ice, are numerous (Marr, 1962; Nast, 1982; Daly and Macauley, 1988; Marschall, 1988; Stretch et al., 1988; Daly, 1990; Melnikov and Spiridonov, 1996; Frazer et al., 1997). There is also some evidence, both from direct observations (Marschall, 1988; Daly, 1990; Brierley et al., 2002) and indirectly from stomach contents of higher predators (Ainley et al., 1987; Daly 
and Macauley, 1988; Ichii and Kato, 1991), of adult krill inhabiting the under-ice environment. The seasonal pattern of advance and retreat of Antarctic sea ice results in an areal change from $4 \times 10^{6} \mathrm{~km}^{2}$ in austral summer to $20 \times 10^{6} \mathrm{~km}^{2}$ in austral winter (Harms et al., 2001). Sea ice drift acts to change the ice distribution. Sea ice moves differently to the underlying ocean; ice motion is generally determined by a combination of wind, ocean currents and internal stress (Steele et al., 1997), with wind dominating on short timescales (Thorndike and Colony, 1982). Therefore, because of the close association of krill with sea ice, the interaction of krill with the sea ice will be important for their subsequent distribution.

Interannual variability in Antarctic sea ice extent (Murphy et al., 1995; White and Peterson, 1996) has been related to population dynamics of krill at the Antarctic Peninsula by affecting recruitment success (Siegel and Loeb, 1995; Quetin and Ross, 2001, 2003). The shelf areas around the Antarctic Peninsula are key spawning areas for krill (e.g. Marr, 1962) and are believed to act as source regions for krill populations downstream (Marr, 1962; Brinton, 1985; Siegel, 1992). The island of South Georgia, lying north of the sea ice zone in the northeast Scotia Sea, is one such area. Influx to South Georgia is particularly important since the island supports large numbers of breeding higher marine predators whose main food source is Antarctic krill. Although krill are capable of reproducing around South Georgia, the eggs and larvae do not contribute to the South Georgia krill populations (Tarling et al., 2006). Instead, the South Georgia krill populations are believed to be maintained by influx from source regions upstream of the island such as the Antarctic Peninsula and the Weddell Sea (e.g. Marr, 1962; Everson, 1977; Brinton, 1985; Maslennikov and Solyankin, 1988; Siegel, 1992).

Because of these advective connections between krill populations, sea ice variability has ecological impacts outside the sea ice zone. The fluctuations in recruitment success at the Antarctic Peninsula, related to sea ice variability, have been noted to affect the South Georgia krill populations (Murphy et al., 1998; Reid et al., 1999; Murphy and Reid, 2001). Biomass estimates fluctuate in concordance across the Scotia Sea (Brierley et al., 1999) suggesting large-scale connections. In addition, krill transport to South Georgia has been linked to winter sea ice in modelling studies (Murphy et al., 1998; Ward et al., 2002; Murphy et al., 2004a). Material ar- 
riving at South Georgia originates from under the sea ice a few months prior to arrival at South Georgia. This suggests that variability in the extent and drift of the sea ice in the Scotia Sea may affect influx to the South Georgia region.

With this research, we advance the earlier advection modelling by incorporating the effect of sea ice motion on transport pathways at circumpolar and regional scales. A Lagrangian particle tracking scheme is used to simulate trajectories in velocity fi elds with and without sea ice motion included to examine the impact of the association of krill with sea ice. We use output from a global numerical ocean circulation model, OCCAM, to provide ocean current information combined with satellite-derived sea ice motion data. Differences between the upper level oceanic motion and that of the sea ice are evident in the model results. Depending on locality, the sea ice acts as either a retention or dispersal mechanism which generates alternative connections between the circumpolar krill population centres. Finally, we investigate the impact of temporal variability in the sea ice and ocean datasets on transport to South Georgia. Variability in the sea ice motion enhances variability in influx to South Georgia and it is shown that anomalous sea ice conditions open up additional source regions for the krill populations at South Georgia.

\section{Data \& Methods}

\subsection{Advection scheme}

To determine transport pathways, we use the Lagrangian particle tracking scheme described by Murphy et al. (2004a). The advection scheme is a second order Runge-Kutta scheme. It has two dimensions spatially and uses time-varying velocity input. Horizontal resolution is $\frac{1}{4}^{\circ} \times \frac{1}{4}^{\circ}$, determined by the velocity fi elds (described below). The components of velocity in the longitude and latitude directions $(u, v)$ at the particle's position are bilinearly interpolated from the four surrounding grid points. A no slip condition is applied at land boundaries. To ensure stability of the scheme, a timestep of 2.4 hours is used which satisfi es the Courant- 
Friedrich-Lewy stability criterion. Diffusion is not treated explicitly within the particle tracking scheme.

\subsection{Ocean velocity data}

The ocean velocity fi elds used in the particle tracking scheme are from the 6 hourly wind forced run of the Ocean Circulation and Climate Advanced Modelling Project (OCCAM) model (Webb et al., 1998; Saunders et al., 1999; Webb and de Cuevas, 2003). OCCAM is a global, eddypermitting $z$ level primitive equation model of the Bryan-Cox-Semtner type and includes a free surface (Killworth et al., 1991). The version used in this research has a horizontal resolution

of $\frac{1}{4}^{\circ} \times \frac{1}{4}^{\circ}$ which gives a longitudinal resolution of $21.3 \mathrm{~km}$ at the northernmost latitude of our study region $\left(40^{\circ} \mathrm{S}\right)$ decreasing to $5.8 \mathrm{~km}$ at the southernmost latitude $\left(78^{\circ} \mathrm{S}\right)$; latitudinal resolution remains constant at $27.8 \mathrm{~km}$. OCCAM has 36 levels in the vertical with thickness ranging from $20 \mathrm{~m}$ at the surface to $255 \mathrm{~m}$ at depth. The run of OCCAM that we use has been forced by the European Centre for Medium-Range Weather Forecasts' 6-hourly reanalysed wind dataset and relaxed to climatological temperature and salinity data (Levitus and Boyer, 1994; Levitus et al., 1994). At the time of our investigations, output from OCCAM was available over the period January 1993-November 2000. OCCAM simulates the circulation of the Scotia Sea reasonably well (Thorpe et al., 2005) and has been used in other modelling studies of this kind (Ward et al., 2002; Murphy et al., 2004a).

Our advection investigations use two different ocean velocity datasets derived from OCCAM velocity output. To examine circumpolar connections, we use a multi-year monthly mean (climatological) velocity dataset, calculated from the monthly mean velocity fi elds from the 8 year period of OCCAM output. The second part of our research, an investigation into the effects of temporal variability in the Scotia Sea, uses time-varying (i.e. not annually-repeating) monthly mean OCCAM velocity output. Both studies use a depth-weighted mean velocity of the upper $182 \mathrm{~m}$ of the water column (levels 1-7 of OCCAM) following Murphy et al. (2004a). The majority of krill biomass is found in this depth range in the summer season (Siegel, 1986; Miller and Hampton, 1989; Watkins et al., 2004). 


\subsection{Sea ice motion data}

The version of OCCAM that we use for the ocean velocity datasets did not incorporate a sea ice model. Since modelled sea ice motion data were not available from OCCAM to go with the ocean velocity output at the time of our study, we instead use Polar Pathfi nder $25 \mathrm{~km}$ sea ice motion vectors provided by the National Snow and Ice Data Center (Fowler, 2003). The sea ice

motion vectors were regridded onto the OCCAM $\frac{1}{4}^{\circ} \times \frac{1}{4}^{\circ}$ horizontal grid and are used in two forms. Firstly, multi-year monthly means (climatology) were calculated from the monthly mean data (available 1978-2003) for the circumpolar transport study. To avoid aliasing the high speed motion at the ice-edge into an unrealistically broad zone when calculating the sea ice motion climatology, we enforced a cut-off point of 12 data points (i.e. $50 \%$ of the available monthly means) in each cell. That is, only cells with 12 or more data points had a mean calculated; the remaining cells were set to zero ice motion. Secondly, the annually-varying, monthly mean (non-climatological) ice motion fi elds were used for the Scotia Sea variability analysis.

\subsection{Combined sea icelocean velocity data}

To incorporate the effects of sea ice motion on the simulated particle trajectories, we use combined sea ice/ocean motion velocity fi elds in the advection scheme. In both velocity datasets described above (circumpolar and Scotia Sea), ocean velocities in areas of sea ice cover (defi ned as those grid cells that have non-zero sea ice motion) are replaced by the corresponding sea ice motion data. In this way, the computational effi ciency of the advection scheme is not compromised; the program need only read in these combined datasets and does not have to make decisions about when to use ice motion in preference to ocean motion.

All the monthly velocity fi elds (whether climatological or monthly mean) are modifi ed according to Killworth (1996) before use in the advection scheme. This avoids errors associated with straightforward linear interpolation between time-varying mean velocity fi elds. 
The circumpolar transport experiment has a circumpolar model domain with open boundaries in the north at $40^{\circ} \mathrm{S}$ and in the south at $78^{\circ} \mathrm{S}$. The northern boundary was defi ned to lie generally north of the Antarctic Circumpolar Current while the southern boundary is defi ned by the extent of OCCAM. Particles were released on a regular grid with horizontal resolution of $2^{\circ}$ in latitude and $4^{\circ}$ in longitude to begin with, and then from areas of krill abundance based on the data in Fig. 1(b). Particles were released on the 1st day of January, April, July and October into the climatological (annually-repeating) velocity fi elds and tracked for a maximum of 3 years in the two different velocity datasets. Once particles leave the model domain via either of the open boundaries they do not reenter the simulation. The general patterns from the seasonal releases are very similar and we therefore present only the January release results, the approximate midmonth of the spawning season of Antarctic krill around the continent (e.g., Spiridonov, 1995).

The Scotia Sea variability investigation covers a study region comprising $50-70^{\circ} \mathrm{S}, 80-20^{\circ} \mathrm{W}$. Particles are released on a grid with horizontal resolution of $0.5^{\circ}$ latitude by $1^{\circ}$ longitude in the area bounded by $59-69^{\circ} \mathrm{S}, 75-35^{\circ} \mathrm{W}$. This release pattern was chosen to cover the source region of particles that reach South Georgia based on preliminary trajectories and as such includes the western Antarctic Peninsula area, the southern Scotia Sea and the northwestern Weddell Gyre, areas of known krill spawning activity (e.g. Marr, 1962). Particles that leave the simulation at an open boundary of the model domain are assumed lost to the system and do not reenter. Particles were released on the 1st day of each month over the period July 1993-May 1999 and tracked for a maximum of one year. Variability in the results was quantifi ed by examining transport to South Georgia, as defi ned by the number of particles entering a predefi ned region around the island. 


\section{Results}

\subsection{Mean circumpolar circulation}

To examine the mean ocean circulation simulated by OCCAM, particles were tracked in the climatological velocity fi elds for 10 years [Fig. 2(a)]. The trajectories show the general circulation of the upper $\sim 200 \mathrm{~m}$ of the Southern Ocean in OCCAM. The modelled circulation is in good agreement with observations (e.g. Gordon et al., 1978; Orsi et al., 1995) with the banded structure of the eastward-fbwing ACC, westward Antarctic Coastal Current and cyclonic gyres of the Weddell and Ross Seas all reproduced.

To compare, the mean sea ice motion averaged over the available data is shown in Fig. 2(b). Emery et al. (1997) described the mean motion of Antarctic sea ice based on an average calculated over a shorter period of time and the same general circulation can be noted here. Westward sea ice motion close to the continent is connected to eastward motion associated with the ACC by areas of northward sea ice movement, particularly from the main coastal embayments of the Weddell and Ross Seas and Prydz Bay.

\subsection{Differences between circumpolar ocean only and sea ice/ocean trajectories}

To examine the differences in particle advection that arise from the inclusion of sea ice motion in the advection scheme, the distance between end points of the simulated trajectories following advection in the two velocity datasets (with and without sea ice motion) after one year was calculated (Fig. 3). 50\% of the particles were affected by sea ice in the first year of advection which resulted in different trajectories in the two advection runs [as defi ned by the particles being more than 1 grid cell apart $\left(0.25^{\circ}\right)$ in either longitude or latitude; Fig. 3]. Particles that do not come into contact with sea ice have the same trajectories in both advection runs since in areas not covered by sea ice the two velocity datasets are identical. Divergence of the particle trajectories in the two simulations, resulting from advection by sea ice rather than the ocean, 
could be as great as $2000 \mathrm{~km}$ after 1 year of advection (mean for particles affected by sea ice $=$ $387.75 \mathrm{~km})$, and more than $6500 \mathrm{~km}$ after 3 years $($ mean $=1003.74 \mathrm{~km})$.

Particles that are affected by sea ice motion in their fi rst year of advection are generally those that are released within the area of maximum sea ice extent. However, not all of the particles released within this area interact with the sea ice (Fig. 3), primarily because of the timing of particle release. The particles were released in January, a month of minimal sea ice cover in the Southern Ocean, and the ocean currents [cf. Fig. 2(a)] are suffi cient to move the particles away from the advancing sea ice so that the particle trajectories are the same in both velocity datasets. In contrast, in limited release areas north of the maximum sea ice extent, the oceanic advection is such as to bring particles into contact with the advancing sea ice (Fig. 3), discussed later.

The model results suggest that there are areas where the sea ice can cause larger differences to the transport pathways than in other locations (Fig. 3). Since our interest lies in the relationship between these advection routes and the large-scale distribution of Antarctic krill, we now examine the trajectories in the two scenarios from particles that originate in areas of krill occurrence as defi ned by Atkinson et al. (2004) [Fig. 1(b)]. For each grid cell with krill numbers above $0 \mathrm{~m}^{-2}, 3$ year trajectories in the two velocity datasets were calculated as before, released on 1 January (Fig. 4). Only the trajectories that are different in the two scenarios are plotted since the mean oceanic circulation is shown in Fig. 2(a).

\subsubsection{SE Pacific/SW Atlantic/Weddell Sea: $90^{\circ} \mathrm{W}-0^{\circ}$}

Particles advected in the ocean only velocity fi elds from this region follow three major transport pathways. These are associated with the Antarctic Coastal Current, the ACC and the Weddell Gyre [Fig. 4(a)]. Those particles released from the southwestern Antarctic Peninsula (south of $\left.\sim 65^{\circ} \mathrm{S}\right)$ and in the Bellingshausen Sea are advected southwards along the western Antarctic Peninsula and westward in the coastal current. Some of these particles remain in the release region for the 3 years of advection while others reach the Ross Sea. Particles released from the northern Antarctic Peninsula are carried eastwards by the ACC into the Scotia Sea. Depending on release location, particles from this region can reach the island of South Georgia within one 
year in the model or can take more than a year to be advected into faster moving fbw, reaching South Georgia in 2 to 3 years. Those particles released in the Weddell Sea are generally caught in the cyclonic circulation of the gyre with some particles crossing into the Scotia Sea. The particles released in the southern Weddell Sea between $30^{\circ} \mathrm{W}-0^{\circ}$ take approximately 1 year to reach the Scotia Sea and 3 years to pass $30^{\circ}$ E. Particles released close to the Antarctic continent in the southern Weddell Sea are generally advected southwards in the model velocity fi elds and exit the model domain. Northward fbw along the eastern Antarctic Peninsula is slow. Advection from the northeastern tip of the Antartic Peninsula takes over a year to transfer material around the tip of the Antarctic Peninsula and it is more than 2 years before the material is entrained into the eastward fbw of the ACC.

Incorporating sea ice motion into the advection scheme affects most of the particles released in this region (Fig. 3). The southwestern Antarctic Peninsula and Bellingshausen Sea particles are moved northward out of the coastal current by the sea ice, increasing retention in this region and limiting westward transport towards the Ross Sea [Fig. 4(b)]. The sea ice provides a connection between the Bellingshausen Sea and the South Shetland Islands $\left(\sim 63^{\circ} \mathrm{S}, 58^{\circ} \mathrm{W}\right)$ north of the Antarctic Peninsula that is not present in the ocean velocity fi elds. The particles released north of the sea ice extent in Drake Passage $\left(\sim 64^{\circ} \mathrm{S}\right)$ follow the same eastward trajectories towards the South Orkney Islands $\left(\sim 60.5^{\circ} \mathrm{S}, 45^{\circ} \mathrm{W}\right)$ for the fi rst 7 months of advection in the two velocity datasets. By this time (austral winter), the sea ice is at its maximum extent in this region and moves the particles more rapidly eastward and via a shorter route than the ocean currents do so that when the sea ice retreats and leaves the particles in the ocean, they are further east than those that were advected without sea ice motion. Particles in the Weddell Sea are moved northwards by the advancing sea ice and as a result there is greater transfer into the eastern Scotia Sea from this region. Transport across the central Weddell Sea is much more rapid when sea ice motion is included and particles are no longer lost over the southern boundary of the model from the southern Weddell Sea. 


\subsubsection{Eastern Weddell Gyre/Prydz Bay: $0^{\circ}-90^{\circ} \mathrm{E}$}

There are two main transport routes for particles released in this region, associated with the Weddell Gyre and the ACC [Fig. 4(c)]. Advection from the southeastern Weddell Gyre transports particles to the Scotia Sea within 2 to 3 years. The northward limb of the gyre advects material from $0^{\circ}$ to $60^{\circ} \mathrm{E}$ in 3 years while the fbw of the central Weddell Gyre in the modelled velocity fi elds is slow. East of $60^{\circ} \mathrm{E}$, particles released north of $\sim 65^{\circ} \mathrm{S}$ are entrained into the ACC following deffection of the fbw fi eld around the Kerguelen Plateau. Some of these particles reach $180^{\circ} \mathrm{W}$ after 3 years of advection. Particles released south of $\sim 65^{\circ} \mathrm{S}$ are advected westward in the coastal current to join the cyclonic circulation of the Weddell Gyre.

The majority of particles released in this region are strongly affected by sea ice motion [Fig. 3, Fig. 4(d)]. Those particles released further west and south are still advected westwards in the coastal current/Weddell Gyre but the northward sea ice motion encountered west of $30^{\circ} \mathrm{E}$ [Fig. 2(b)] advects the particles out of the westward current and north across the Weddell Gyre. This cuts off the connection to the Scotia Sea from this region. Particles released north of the maximum sea ice extent around $60^{\circ} \mathrm{E}$ (north of $60^{\circ} \mathrm{S}$ ) are affected by sea ice. The ocean velocity fi elds take the particles southeastward where the particles encounter the sea ice in austral winter. As with the Drake Passage particles, the sea ice motion in this region provides a shorter transport route than the ocean only motion and so the particles in the sea ice/ocean velocity fi elds are advected further in the same time period.

\subsubsection{Dumont d'Urville Sea: $90^{\circ} \mathrm{E}-180^{\circ}$}

West of $150^{\circ} \mathrm{E}$ in this region, oceanic transport is dominated by the westward fbw of the Antarctic Coastal Current [Fig. 4(a)]. Most particles are advected westward to $80^{\circ} \mathrm{E}$ where the fbw diverges; from here some particles continue westward, reaching the Cosmonaut Sea in 3 years in the model, and others are taken northwards to join the ACC by deftection in the fbw caused by the Kerguelen Plateau. Recirculation in the Dumont d'Urville Sea, centred at $\sim 120^{\circ} \mathrm{E}$, is apparent in the particle trajectories (cf. Nicol et al., 2000). East of $150^{\circ} \mathrm{E}$, most particles are advected eastward in the ACC with connection to the Amundsen Sea within the 3 years of 
transport. There is some retention offshore of the Antarctic continent at $\sim 165^{\circ} \mathrm{E}$.

When sea ice motion is included [Fig. 4(b)], divergence of the advection pathways from this region still occurs at $\sim 150^{\circ} \mathrm{E}$. West of $150^{\circ} \mathrm{E}$, the Antarctic Coastal Current carries particles westward but all particles are defected northwards by the Kerguelen Plateau so that there is no longer any transport to the eastern Weddell Gyre. The gyre observed at $120^{\circ} \mathrm{E}$ in the ocean only velocity fi elds is still apparent in the combined sea ice/ocean advection. West of $\sim 150^{\circ} \mathrm{E}$, sea ice advects all particles northwards into the ACC so that there is increased eastward transport, reaching as far east as the Bellingshausen Sea in 3 years.

\subsubsection{Ross Sea, Amundsen Sea: $180^{\circ}-90^{\circ} \mathrm{W}$}

The dominant oceanic feature in this region is the Ross Gyre [Fig. 4(c)] which can retain particles for the 3 years of simulation. Particles released on the eastern side of the cyclonic gyre are advected southwards and then westwards once entrained into the coastal current. This provides a transport pathway along the Antarctic continent as far as $105^{\circ} \mathrm{E}$. Particles released west of the Ross Gyre are carried eastwards by the ACC. Some of the particles that originate in the Bellingshausen Sea (east of $\sim 100^{\circ} \mathrm{W}$ ) are retained in their source region while others are taken westward to the southern Ross Sea.

The inclusion of sea ice motion modifi es these advection pathways substantially [Fig. 4(d)] and all particles are affected (Fig. 3). Apart from some retention in the western Amundsen Sea, the sea ice advects all particles northwards out of the coastal current and across the gyre into the ACC. There is no longer any retention associated with the Ross Gyre nor westward transport in the Antarctic Coastal Current; instead, transport is eastward with the ACC. This opens up a connection between the Ross Sea and the Scotia Sea, and from the Amundsen and Bellingshausen Seas to the western Antarctic Peninsula. 


\subsection{Scotia Sea variability}

So far we have considered advection in climatological (annually-repeating) monthly mean ocean velocity and sea ice motion fi elds. We now go on to examine the impacts of temporal variability in the two datasets on transport pathways across the Scotia Sea. We quantify the results by focussing on transport to South Georgia. Thorpe et al. (2004) previously investigated temporal variability in oceanic transport to South Georgia using output from a different global ocean circulation model, the Semtner/Chervin Parallel Ocean Climate Model, and found that changes in regional ocean circulation were important. Our investigation extends this research by considering the impacts of sea ice variability.

Incorporating sea ice motion into the advection scheme provides different source regions for particles that reach South Georgia than do models that include only oceanic transport (Fig. 5). Particles in the ocean velocity fi elds that reach South Georgia within a year (as defi ned by the dashed box around South Georgia marked on Fig. 5) generally originate from a restricted area in the north of the release region that includes the northern Antarctic Peninsula and the South Scotia Ridge. Particles released further south along the peninsula and from the Weddell Sea have little if any chance of being advected to South Georgia in the modelled ocean velocity fi elds at this depth [Fig. 5(a)]. For the particles advected in the sea ice/ocean velocity fi elds, the same northern source regions are evident but, in addition, particles have some chance of reaching South Georgia from the Weddell Sea and further east along the South Scotia Ridge when the sea ice motion is included [Fig. 5(b)].

During the 6 year period of monthly particle releases, the probability of particles reaching South Georgia from each monthly release as a whole is very similar in both the ocean only tracking and the sea ice/ocean tracking [Fig. 6(a)] suggesting that the ocean signal dominates at these times. Periods when the two series differ show the contribution of sea ice variability. During the early part of the series (January 1993-October 1994) there is a slightly higher probability of particles in the sea ice/ocean velocity fi elds reaching South Georgia. Later in the series, the difference is more substantial with a $50 \%$ increase in the probability of reaching South Geor- 
gia in the sea ice/ocean velocity fi elds from releases made in austral autumn 1997. In terms of transport time to South Georgia from the release sites, we consider only those particles that reach South Georgia from each monthly release and calculate the average time taken by these monthly subsets of particles [Fig. 6(b)]. The average time taken ranges from $\sim 130-250$ days in both series. For much of the tracking period, the two series are very similar but there are differences when particles subjected to sea ice motion take longer to reach South Georgia than those advected in the ocean only velocity fi elds (e.g. austral winter 1995 and austral autumn/winter 1997). Despite the seasonal pattern of sea ice advance and retreat which might be expected to affect the probability of particles reaching South Georgia, there does not appear to be a strong seasonal pattern in the results.

When the number of particles that arrive at South Georgia in any given month (a function of the probability of reaching South Georgia and the associated travel time of each particle) is considered, it is clear that variability is increased with the inclusion of sea ice motion in the advection scheme [Fig. 6(c)]. While influx of particles advected to South Georgia in the ocean only velocity fi elds is relatively steady with particles arriving each month, including sea ice motion concentrates the particles into pulses of arrival. For example, there are months of almost zero influx when sea ice motion is included (October-November 1995, October 1997, November 1997) together with months of much higher than usual influx (December 1993, October 1994, March 1995, January 1996 and January-March 1998). These periods of increased influx in the sea ice/ocean particle time series tend to coincide with peaks of increased average 'age' of the particles arriving at South Georgia each month [Fig. 6(d)]—i.e. the average time taken to reach South Georgia by the ensemble of particles that reach the island each month. The largest positive effect on influx to South Georgia caused by the sea ice motion variability occurred in austral summer 1998, an anomalous year in terms of summer sea ice extent in the Weddell Sea (cf. Ackley et al., 2001) with the sea ice remaining north of the South Scotia Ridge $\left(\sim 61^{\circ} \mathrm{S}\right)$ from winter 1997 until summer 1997/1998 [Fig. 6(e)]. The anomalous northward extent of the sea ice in November and December provided a means of transport for particles from further south than usual and advected the particles that were in association with the sea ice further north than normal. Sea ice retreat then deposited the particles into the southern part of the ACC 
from where they were transported to South Georgia in the ocean currents. The particles reached South Georgia the following January-March 1998 [Fig. 6(c)] having spent some time within the ice and thereby increasing the average 'age' of the particles reaching South Georgia during that period of time by more than two months [Fig. 6(d)].

In a recent modelling study, Fach and Klinck (2006) also examined krill transport to South Georgia. They employed a regional ocean circulation model, the Harvard Ocean Prediction System (HOPS), and simulated transport at $50 \mathrm{~m}$ depth for a run of 10 month duration without interaction with sea ice. Their results identifi ed fi ve potential source regions for krill at South Georgia at that depth and within that timeframe: the western Antarctic Peninsula, Bransfi eld Strait, Scotia Sea/Elephant Island, the southwestern Antarctic Peninsula and the Weddell Sea (their Fig. 11). Our study, using a greater depth (average of the upper $\sim 200 \mathrm{~m}$ of the water column), suggests that the South Scotia Ridge is a key source region for South Georgia krill when advected in ocean currents only and that the inclusion of sea ice motion adds the northwestern Weddell Sea as a source region and enhances the potential transport from the area of the South Shetland Islands (Fig. 5). Results using a shallower depth-weighted mean calculated from the OCCAM velocity fi elds (the upper $64 \mathrm{~m}$ of the water column; not shown) indicate the same source regions for krill at South Georgia as the results of Fach and Klinck (2006). This difference in source regions is most likely due to the increased northward motion associated with Ekman transport at the shallower depths which quickly moves particles northwards into the faster-fbwing offshore currents, as noted by Hofmann et al. (1998).

In terms of importance of the timing of particle release for most successful transport of krill to South Georgia, Fach and Klinck (2006) made three releases of particles in their model in December, January and February. An early release (i.e. December) increased the number of particles reaching South Georgia in their simulation. Our results (Fig. 6), based on monthly releases made over 6 years, do not show such a straightforward pattern but instead suggest that interannual variability in the ocean circulation is important, particularly with respect to transport time across the Scotia Sea. 


\section{Discussion}

\subsection{Physical assumptions of the model}

The circumpolar trajectories that we present are dependent on the ability of the ocean model, OCCAM, to simulate a realistic circulation in our study area. Circumpolar validation of OCCAM in the Southern Ocean has not been carried out but studies in the Scotia Sea region show that OCCAM reproduces the frontal structure of the southern ACC with realistic velocities (albeit slightly increased) and transports (Thorpe et al., 2002, 2005). There are discrepancies in the position of the southern Antarctic Circumpolar Current front in the Scotia Sea in OCCAM (Thorpe et al., 2005) but this does not affect transport times to South Georgia when compared with historical drifter data for example. Mean transport times in the upper ocean of OCCAM from the Antarctic Peninsula to South Georgia of 160 days reported by Murphy et al. (2004a) agree with near-surface drifter trajectories in the same region (Thorpe, 2001). This suggests that those particles advected in the ACC fronts in our study will have realistic transport times. Background transport will likely be slower in the model than in the ocean due to the horizontal resolution of the model and the use of the monthly mean velocity fi elds in our advection scheme which reduces mesoscale effects. This should be borne in mind when the transport times in such regions are considered.

Use of monthly mean velocity fi elds (both for the ocean circulation and the sea ice motion) reduces the amount of higher frequency and mesoscale variability in our results and will somewhat smooth the particle trajectories. Whilst this is acceptable for the present study, use of higher temporal resolution velocity fi elds where available would be a useful progression of the circumpolar transport model and would in particular allow a more detailed representation of the seasonal sea ice growth and retreat cycle. The lack of a sea ice model in OCCAM led us to use satellite data for the sea ice motion. This ensures realistic movement of the sea ice but use of a coupled sea ice-ocean model will allow investigation of the fate of krill that are beneath the sea ice but not directly attached to it. As such, our results show the maximum likely effects of the interaction with sea ice but it is likely that observed pathways would be somewhere between the 
two scenarios.

\subsection{Biological assumptions of the model}

Our model makes some basic biological assumptions about the behaviour and life cycle of Antarctic krill. The ontogenesis of krill involves vertical movement through the water column to a depth of 500-800 m and generally takes 12-30 days (Hofmann and Hüsrevoğlu, 2003; Tarling et al., 2006). We have not included this developmental cycle in our model. Krill are active in their environment from an early stage, becoming more mobile and capable of faster swimming speeds with age (Kils, 1982). It is likely that they can respond to ambient food concentrations, water temperature and predation. We assume the net effect of these smallerscale movements is random and do not include them in our model. While directed horizontal migration by krill has been inferred in coastal regions (Siegel, 1988), there is no evidence that krill show directed migration in oceanic regions. If krill are capable of these longer, directed movements, the areas where this will have most effect is in regions of slower moving currents. In the faster ocean jets found in the Southern Ocean where speeds often exceed the maximum swimming speed of krill, the currents are likely to dominate over the krill movement (Murphy et al., 2004a,b); however, movements into and out of the jets will be important in determining subsequent transport pathways.

Diel vertical migration (DVM) has been well-observed in euphausiids and has been reported for Antarctic krill in the summer season (Miller and Hampton, 1989) and more recently over an annual cycle using fi shing depth data as a proxy for krill depth (Taki et al., 2005). Murphy et al. (2004a) investigated the effect of incorporating simple DVM into model simulations using the same advection scheme as this study. They found that on the large-scale the DVM scheme had little impact on the trajectories as compared with using a depth-weighted mean velocity fi eld over the same depth range. Thus, by using the depth-weighted mean velocity fi elds in our simulations we have to some extent included the effects of this aspect of krill behaviour. More complex DVM patterns, where for example the krill spend a larger proportion of time in the surface layer of the ocean than at depth, would affect the trajectories (c.f. Murphy et al., 2004a) 
but have not been included. The differences noted above between our results and those of Fach and Klinck (2006) suggest that the depth range used to simulate krill transport is important, particularly at a regional scale. Hence, future models that further examine this matter should use the appropriate depth for the appropriate stage of the krill life cycle.

A further caveat of our model is that the depth range that we have chosen for the oceanic advection is representative of the summer season. Recent data suggest that Antarctic krill have a seasonally-varying DVM cycle with deeper vertical distribution and a greater amplitude of DVM in winter (Taki et al., 2005, and see also Siegel (2005)). Our model does not simulate this particular aspect of behaviour but future runs will examine the impact of these seasonal changes.

In relation to krill behaviour associated with sea ice, our model assumes that when sea ice is present krill are moved directly with the sea ice rather than in the water column below the ice. We have assumed no dispersal under the sea ice; movements by the krill under the ice could introduce further variability and will be worth considering in future studies. There is a lot of evidence that smaller larval and juvenile krill are found in sea ice habitats on the under-surface of the ice or in brine channels within the ice, feeding on the ice algae (e.g. Quetin and Ross, 2003). Sea ice algae provide an over-winter food source for krill that appears particularly crucial for the larvae and juveniles that have little energy storage capacity (e.g. Ross and Quetin, 1989; Meyer et al., 2002). For these younger krill that are closely associated with the sea ice (Frazer et al., 1997), it is likely that they are transported with the sea ice as it is moved. For adult krill, the situation appears more complex. There are reports of adult krill under the sea ice (Marschall, 1988) but there are also studies that have suggested that adult krill show little association with sea ice (Guzman, 1983) and that in some areas the krill are found in the water column below the ice (Daly and Macauley, 1988), at depth below the mixed layer (Holzlöhner, 1980) or even in association with the sea bed (Gutt and Siegel, 1994). In spring, adult krill are found in the marginal ice zone (e.g. Brierley et al., 2002). This may be where the animals overwintered or the result of physical-biological interaction generating aggregations of krill. This complexity of apparent responses of adult krill to sea ice habitats may partly be explained by the heterogeneity 
of the sea ice environments (Quetin and Ross, 1991), which may generate very different overwinter habitats. Our approach thus generates the maximum effect that association with sea ice may have on the distribution of krill populations.

Finally, we have presented results for the circumpolar trajectories from particles released on 1st January. The krill spawning season occurs between November and April, depending on location (Spiridonov, 1995), and krill are capable of multiple spawnings in good conditions (Ross and Quetin, 1983; Cuzin-Roudy, 1987a,b, 2000; Quetin and Ross, 2001; Tarling et al., 2006). Variability in the timing of spawning will affect interactions with the changing sea ice distribution so that, although on the large scale the main transport routes remain the same, locally there could be differences in the timescales of retention and transport pathways as observed from the Scotia Sea results.

\subsection{Circumpolar transport}

The traditional view of circumpolar connections in the Southern Ocean is dominated by the role of the eastward-fbwing ACC (e.g. Hofmann and Murphy, 2004). While this research has shown the ACC to be important, it has also highlighted the connections provided by the westwardfbwing Antarctic Coastal Current which appears to connect many of the regions of higher krill density. For example, the Antarctic Coastal Current provides a connection between the regions of increased krill density in the Dumont d'Urville Sea to those in Prydz Bay, to the Cosmonaut Sea and ultimately, via the Lazarev and Weddell Seas, to the Scotia Sea. The Coastal Current can transport material as quickly as the ACC in our simulations so that in some places such as the Scotia Sea material can arrive from opposite sides of the Antarctic continent (Ross Sea and Cosmonaut Sea) on the same timescales (Fig. 7). [Note that the pattern of krill abundance shown in Fig. 1(b) suggests that the western Antarctic Peninsula is likely to be the dominant source region for krill at South Georgia.] This suggests that one of the reasons why the Scotia Sea is a consistently high density krill region [Atkinson et al. (2004); Fig. 1(b)] is the existence of these convergent pathways, where fbws from Drake Passsage and further west meet water from the Weddell Sea region and further east. This convergence of fbws from potential source 
regions may help to explain the asymmetrical krill distribution (Marr, 1962).

Regions of transfer between the ACC and the Coastal Current can create areas of retention around the continent, for example along the western Antarctic Peninsula to the Bellingshausen and Amundsen Seas, and in the Dumont d'Urville Sea. On longer timescales ( $\sim 10$ years; data not shown), advection within the Weddell Gyre forms a closed loop and provides a means of population retention in that region.

Considering interactions with sea ice increases the complexity of the potential connections between krill populations. The model has shown that sea ice interactions will be important in determining the spatial links that occur in Southern Ocean ecosystems. Sea ice-related drift can modify the pathways of transport, generating regional connections between areas that are isolated in the mean circulation view. For example, sea ice motion enables northward transfer along the western Antarctic Peninsula connecting the Bellingshausen Sea to the tip of the Antarctic Peninsula (i.e. the opposite direction to the mean ocean circulation) and ultimately towards South Georgia, as well as more rapid transfer from the southern Weddell Sea into the Scotia Sea. In other regions, the interaction with sea ice motion impedes some of the oceanic connectionsprimarily those associated with the Coastal Current, for example there is no longer any westward transfer from the western Antarctic Peninsula to the Amundsen Sea, nor transfer from Prydz Bay to the Scotia Sea. The potential for enhancement or indeed reduction of regional retention of krill (e.g. the southwestern Antarctic Peninsula and the Ross Sea respectively) is generated by the inclusion of sea ice-related motion. Clearly, smaller-scale processes such as mesoscale features and temporal variability will be important in generating transfer between the main pathways of transport illustrated in our results and future work will focus on this matter.

Krill spawning can occur throughout much of the Southern Ocean, but the capacity for successful spawning, whereby the egg can sink to a required depth for hatching and the larva is able to return to the surface using its energy reserves, will depend on local and historical conditions for feeding and temperature. A modelling study by Hofmann and Hüsrevoğlu (2003) showed that there are specific locations on the continental shelf around Antarctica where the environmental conditions (water temperature and depth) are more suited to successful spawn- 
ing [in waters deeper than 1000 m, Hofmann and Hüsrevoğlu (2003) found no constraints on successful spawning due to the presence of Circumpolar Deep Water]. Key regions for successful spawning were found to be on the continental shelves of the western Antarctic Peninsula, the Bellingshausen and Amundsen Seas and the Dumont d'Urville Sea. It is in these localities that the advective transport will be especially crucial and where the accurate representation of the sea ice/ocean contributions to the advection will be important. Our modelling study has shown that these are regions where including the sea ice motion can have a large impact on the resultant advection.

We stress that the circumpolar model uses climatological, monthly mean velocity fi elds for these simulations. The use of climatological velocity fi elds means that while the particle trajectories illustrate the mean interactions between the ocean circulation and the sea ice motion, interannual variability is not considered. Changes from year to year in both ocean circulation patterns (e.g. frontal positions, increased mesoscale variability) and sea ice motion and extent will affect these general pathways (as shown in the Scotia Sea investigation). In addition, the monthly mean velocity fi elds smooth out some of the mesoscale variability of this region and mean that particles are released from the sea ice more rapidly than they might be in reality. Furthermore, we have not explicitly included diffusion. Mesoscale variability and diffusion will be important physical processes, potentially increasing retention, transfer from one oceanic current system to another and contact with sea ice depending on location. There are clearly regions where these smaller-scale motions (and those of the krill themselves) could have a big impact on the krill distribution. For example, between $0^{\circ}-30^{\circ} \mathrm{W}$ some southward motion, due to sea ice retreat or eddying motion perhaps, could move the krill into the Weddell Gyre rather than continuing eastward with the ACC. While we are interested in the mean pathways for this research, it would be useful for future simulations to include such processes.

\subsection{Scotia Sea variability}

To investigate interannual variability, we chose a smaller study region focussing on the Scotia Sea, an area of particularly high krill density. Studies at South Georgia have shown interan- 
nual variability in local krill abundance, related to variability in recruitment upstream and to variability in transport to the island (Brierley et al., 1997; Murphy et al., 1998; Murphy and Reid, 2001; Trathan et al., 2003; Thorpe et al., 2004). Sea ice motion in the Weddell Sea exhibits mesoscale variability that was evident in the monthly mean motion dataset employed in our model. Speed of the sea ice drift during our study period ranged from almost stationary to approximately $15 \mathrm{~cm} \mathrm{~s}^{-1}$, comparable to the swimming speed of adult krill.

The model results have shown that variability in sea ice motion increases variability in transport to South Georgia. For a lot of the time, the variability introduced by the oceanic variability dominates the signal but in years of extreme sea ice extent, then the sea ice introduces additional variability into the Scotia Sea transport. These periods when the sea ice does make a difference will be important for the South Georgia krill populations and therefore to the krill-dependent predators that breed on South Georgia.

Observations of length-frequency distribution made at South Georgia have suggested different source regions for the island's krill population with very small krill noted in association with Weddell Sea water, suggesting occasional transport from the Weddell Sea to South Georgia (Watkins et al., 1999; Siegel et al., 2004). Our model results suggest that interaction with sea ice fosters additional source regions for krill at South Georgia, especially in years of anomalous ice extent when more particles reach South Georgia from the northern Weddell Sea. Sea ice extent in the Scotia Sea and circumpolarly has been observed to have a periodicity of variability (Murphy et al., 1995; White and Peterson, 1996); our results suggest that, while a longer time series is required to fully investigate the impacts, this has further implications for the South Georgia ecosystem.

\section{Conclusions}

The modelling studies presented here have important results for the consideration of spatial connections between the circumpolar populations of Antarctic krill. The Antarctic Coastal Current can connect the near-continental regions of higher krill density while the ACC provides 
transport in the opposite direction at lower latitudes. Transfer between these current systems, either by mesoscale ocean features, movement with sea ice or small-scale krill movements for example, will affect regional dispersal or retention which could enhance population stability.

The interaction with sea ice is a key part of the life cycle of Antarctic krill and the differences in transport generated by over-winter association with sea ice environments revealed in this study will have a major effect on krill population distribution. Interaction with sea ice can further increase regional population retention or dispersal. The association with sea ice provides more options whereby the smaller-scale behavioural/development changes of Antarctic krill can affect the regional and circumpolar distribution. For example, the interaction with sea ice in winter during early life stages followed by ocean-dominated interaction and transport during the adult stages may generate alternate directions of drift and be an aspect of the life cycle that gives rise to population retention. These interactions will be particularly important in the high krill density regions of the Antarctic Peninsula and Scotia Sea.

On a regional scale, temporal and spatial variability in sea ice cover and motion increases variability in oceanic transport to South Georgia, both in terms of influx to the island and in timescales of transport. This is likely to impact on the krill populations at South Georgia and the higher predators that depend on these populations. Variability associated with the sea ice will also be important at other circumpolar locations, particularly in areas of spawning.

Future work will develop these hypotheses. The availability of higher resolution coupled oceansea ice models will allow investigation of more detailed scenarios of krill-sea ice associations, while including more biological aspects of krill will allow closure of the krill life cycle. Our work has shown that it is crucial to better resolve these interactions.

\section{Acknowledgements}

We thank Beverly de Cuevas at the National Oceanography Centre, Southampton for providing the OCCAM output and the National Snow and Ice Data Center, Boulder for the sea ice motion 
data. The OI.v2 Monthly SST Analysis data were provided by the Data Support Section of the Scientifi c Computing Division at the National Center for Atmospheric Research. NCAR is supported by grants from the National Science Foundation. We are grateful to members of the British Antarctic Survey (BAS) DISCOVERY 2010 core programme and Prof. Eileen Hofmann for useful discussions. Angus Atkinson kindly provided the krill density data for Figure 1(b). We thank the reviewers of this paper and the journal editor for their comments which helped us improve the original version. This research forms a contribution to the BAS DISCOVERY 2010 programme. 


\section{References}

Ackley, S. F., Geiger, C. A., King, J. C., Hunke, E. C., and Comiso, J. (2001). The Ronne polynya of 1997/98: observations of air-ice-ocean interaction. Ann. Glaciol., 33, 425-429.

Ainley, D. G., Fraser, W. R., and Daly, K. (1987). Effects of pack ice on the composition of micronektonic communities in the Weddell Sea. Seminar on Antarctic Ocean variability and its influence on marine living resources, particularly krill. CCAMLR/IOC, Paris.

Atkinson, A., Whitehouse, M. J., Priddle, J., Cripps, G. C., Ward, P., and Brandon, M. A. (2001). South Georgia, Antarctica: a productive, cold water, pelagic ecosystem. Mar. Ecol. Prog. Ser., 216, 279-308.

Atkinson, A., Siegel, V., Pakhomov, E., and Rothery, P. (2004). Long-term decline in krill stock and increase in salps within the Southern Ocean. Nature, 432, 100-103.

Banse, K. (1995). Zooplankton-Pivotal role in the control of ocean production. ICES J. Mar. Sci., 52, 265-277.

Brierley, A. S., Watkins, J. L., and Murray, A. W. A. (1997). Interannual variability in krill abundance at South Georgia. Mar. Ecol. Prog. Ser., 150, 87-98.

Brierley, A. S., Demer, D. A., Watkins, J. L., and Hewitt, R. P. (1999). Concordance of interannual fluctuations in acoustically estimated densities of Antarctic krill around South Georgia and Elephant Island: biological evidence of same-year teleconnections across the Scotia Sea. Mar. Biol., 134, 675-681.

Brierley, A. S., Fernandez, P. G., Brandon, M. A., Armstrong, F., Millard, N. W., McPhail, S. D., Stevenson, P., Pebody, M., Perrett, J., Squires, M., Bone, D. G., and Griffi ths, G. (2002). Antarctic krill under sea ice: elevated abundance in a narrow band just south of ice edge. Science, 295(5561), 1890-1892.

Brinton, E. (1985). The oceanographic structure of the eastern Scotia Sea-III. distributions of euphausiid species and their developmental stages in 1981 in relation to hydrography. DeepSea Res., 32(10), 1153-1180.

Croxall, J. P., McCann, T. S., Prince, P. A., and Rothery, P. (1988). Reproductive performance of seabirds and seals at South Georgia and Signy Island, South Orkney Islands, 1976-1987: implications for Southern Ocean monitoring studies. In D. Sahrhage, editor, Antarctic Ocean 
and Resources Variability, pages 261-285. Springer-Verlag.

Cuzin-Roudy, J. (1987a). Gonad history of Antarctic krill Euphausia superba Dana during its breeding season. Polar Biol., 7, 237-244.

Cuzin-Roudy, J. (1987b). Sexual differentiation in the Antarctic krill Euphausia superba Dana (Crustacea: Euphausiacae). J. Crustac. Biol., 7, 518-524.

Cuzin-Roudy, J. (2000). Seasonal reproduction, multiple spawning and fecundity in Northern krill, Meganyctiphanes norvegica, and Antarctic krill, Euphausia superba. Can. J. Fish. Aquat. Sci., 57, 6-15.

Daly, K. L. (1990). Overwintering development, growth, and feeding of larval Euphausia superba in the Antarctic marginal ice zone. Limnol. Oceanogr., 35(7), 1564-1576.

Daly, K. L. and Macauley, M. C. (1988). Abundance and distribution of krill in the ice edge zone of the Weddell Sea, austral spring 1983. Deep-Sea Res., 35(1), 21-41.

Emery, W. J., Fowler, C. W., and Maslanik, J. A. (1997). Satellite-derived maps of Arctic and Antarctic sea ice motion: 1988 to 1994. Geophys. Res. Lett., 24(8), 897-900.

Everson, I. (1977). The living resources of the Southern Ocean. Technical Report GLO/SO/77/1, Rome: Food and Agricultural Organization. 156 pp.

Fach, B. A. and Klinck, J. M. (2006). Transport of Antarctic krill (Euphausia superba) across the Scotia Sea. Part I: Circulation and particle tracking simulations. Deep-Sea Res. I, 53, 987-1010.

Fach, B. A., Hofmann, E. E., and Murphy, E. J. (2002). Modeling studies of Antarctic krill Euphausia superba survival during transport across the Scotia Sea. Mar. Ecol. Prog. Ser., 231, 187-203.

Fach, B. A., Hofmann, E. E., and Murphy, E. J. (2006). Transport of Antarctic krill (Euphausia superba) across the Scotia Sea. Part II: Krill growth and survival. Deep-Sea Res. I, 53, 10111043.

Fasham, M. J. R., Ducklow, H. W., and McKelvie, S. M. (1990). A nitrogen-based model of plankton dynamics in the oceanic mixed layer. J. Mar. Res., 48, 591-693.

Fowler, C. (2003). Polar Pathfi nder Daily 25 km EASE-Grid Sea Ice Motion Vectors. Digital media, National Snow and Ice Data Center, Boulder, CO, USA.

Frazer, T. K., Quetin, L. B., and Ross, R. M. (1997). Abundance and distribution of larval krill, 
Euphausia superba, associated with annual sea ice in winter. In B. Battaglia, J. Valencia, and D. W. H. Walton, editors, Antarctic Communities: Species, Structure and Survival, pages 107-111. Cambridge University Press.

Gordon, A. L., Molinelli, E., and Baker, T. (1978). Large-scale relative dynamic topography of the Southern Ocean. J. Geophys. Res., 83(C6), 3023-3032.

Gutt, J. and Siegel, V. (1994). Benthopelagic aggregations of krill (Euphausia superba) on the deeper shelf of the Weddell Sea (Antarctic). Deep Sea Res. I, 41(1), 169-178.

Guzman, O. (1983). Distribution and abundance of Antarctic krill (Euphausia superba) in the Bransfi eld Strait. In On the biology of krill, Euphausia superba, volume 4, pages 169-190. Ber. Polarforsch. Sonderheft.

Harms, S., Fahrbach, E., and Strass, V. H. (2001). Sea ice transports in the Weddell Sea. J. Geophys. Res., 106(C5), 9057-9073.

Heath, M. R., Boyle, P. R., Gislason, A., Gurney, W. S. C., Hay, S. J., Head, E. J. H., Holmes, S., Ingvarsdottir, A., Jonasdottir, S. H., Lindeque, P., Pollard, R. T., Rasmussen, J., Richards, K., Richardson, K., Smerdon, G., and Speirs, D. (2004). Comparative ecology of over-wintering Calanus finmarchicus in the northern North Atlantic, and implications for life-cycle patterns. ICES J. Mar. Sci., 61(4), 698-708.

Hofmann, E. E. and Hüsrevoğlu, Y. S. (2003). A circumpolar modeling study of habitat control of Antarctic krill (Euphausia superba) reproductive success. Deep-Sea Res. II, 50, 31213142.

Hofmann, E. E. and Lascara, C. M. (2000). Modelling the growth dynamics of Antarctic krill Euphausia superba. Mar. Ecol. Prog. Ser., 194, 219-231.

Hofmann, E. E. and Murphy, E. J. (2004). Advection, krill, and Antarctic marine ecosystems. Ant. Sci., 16(4), 487-499.

Hofmann, E. E., Klinck, J. M., Locarnini, R. A., Fach, B., and Murphy, E. (1998). Krill transport in the Scotia Sea and environs. Ant. Sci., 10(4), 406-415.

Holzlöhner, S. (1980). Beobachtungen am Krill (Euphausia superba Dana) in der antarcktischen Sommersaison 1977/78 vor Südgeorgien. Fischerei-Forschung, 18, 15-17.

Ichii, T. and Kato, H. (1991). Food and daily food consumption of southern minke whales in the Antarctic. Polar Biol., 11, 479-487. 
Killworth, P. D. (1996). Time interpolation of forcing fi elds in ocean models. J. Phys. Oceanogr., 26(1), 136-143.

Killworth, P. D., Stainforth, D., Webb, D. J., and Paterson, S. M. (1991). The development of a free surface Bryan-Cox-Semtner ocean model. J. Phys. Oceanogr., 21, 1333-1348.

Kils, U. (1982). Swimming behavior, swimming performance and energy balance of Antarctic krill Euphausia superba. BIOMASS Scientific Series, 3, 1-122.

Levitus, S. and Boyer, T. (1994). World Ocean Atlas 1994 Volume 4: Temperature. NOAA Atlas NESDIS 4, U.S. Department of Commerce, Washington, D.C.

Levitus, S., Burgett, R., and Boyer, T. (1994). World Ocean Atlas 1994 Volume 3: Nutrients. NOAA Atlas NESDIS 3, U.S. Department of Commerce, Washington, D.C.

Loeb, V., Siegel, V., Holm-Hansen, O., Hewitt, R., Fraser, W., Trivelpiece, W., and Trivelpiece, S. (1997). Effects of sea-ice extent and krill or salp dominance on the Antarctic food web. Nature, 387(6636), 897-900.

Marr, J. (1962). The natural history and geography of the Antarctic krill Euphausia superba Dana. Discovery Rep., 32, 33-464.

Marschall, H.-P. (1988). The overwintering strategy of Antarctic krill under the pack-ice of the Weddell Sea. Polar Biol., 9, 129-135.

Maslennikov, V. V. and Solyankin, E. V. (1988). Patterns of fluctuations in the hydrological conditions of the Antarctic krill and their effect of the distribution of Antarctic krill. In D. Sahrhage, editor, Antarctic Ocean and Resources Variability, pages 209-213. SpringerVerlag.

Melnikov, I. A. and Spiridonov, V. A. (1996). Antarctic krill under perennial sea ice in the western Weddell Sea. Ant. Sci., 8(4), 323-329.

Meyer, B., Atkinson, A., Stubing, D., Oetti, B., Hagen, W., and Bathmann, U. V. (2002). Feeding and energy budgets of Antarctic krill Euphausia superba at the onset of winter-I. Furcilia III larvae. Limnol. Oceanogr., 47(4), 943-952.

Miller, D. G. M. and Hampton, I. (1989). Biology and ecology of the Antarctic krill (Euphausia superba Dana): A review, volume 9 of BIOMASS Scientific Series. SCAR, SCOR and Scott Polar Res. Inst., Cambridge, UK.

Murphy, E. J. and Reid, K. (2001). Modelling Southern Ocean krill population dynamics: 
biological processes generating fluctuations in the South Georgia ecosystem. Mar. Ecol. Prog. Ser., 217, 175-189.

Murphy, E. J., Clarke, A., Symon, C., and Priddle, J. (1995). Temporal variation in Antarctic sea-ice: analysis of a long term fast-ice record from the South Orkney Islands. Deep-Sea Res. I, 42(7), 1045-1062.

Murphy, E. J., Watkins, J. L., Reid, K., Trathan, P. N., Everson, I., Croxall, J. P., Priddle, J., Brandon, M. A., Brierley, A. S., and Hofmann, E. (1998). Interannual variability of the South Georgia marine ecosystem: biological and physical sources of variation in the abundance of krill. Fish. Oceanog., 7(3/4), 381-390.

Murphy, E. J., Thorpe, S. E., Watkins, J. L., and Hewitt, R. (2004a). Modeling the krill transport pathways in the Scotia Sea: spatial and environmental connections generating the seasonal distribution of krill. Deep-Sea Res. II, 51, 1435-1456.

Murphy, E. J., Watkins, J. L., Meredith, M. P., Ward, P., Trathan, P. N., and Thorpe, S. E. (2004b). Southern Antarctic Circumpolar Current Front to the northeast of South Georgia: Horizontal advection of krill and its role in the ecosystem. J. Geophys. Res., 109(C01029), doi:10.1029/2002JC001522.

Nast, F. (1982). The assessment of krill (Euphausia superba Dana) biomass from a net sampling programme. Meeresforschung, 29, 154-165.

Nicol, S., Pauly, T., Bindoff, N. L., and Strutton, P. G. (2000). "BROKE” a biological/oceanographic survey off the coast of East Antarctica $\left(80-150^{\circ} \mathrm{E}\right)$ carried out in JanuaryMarch 1996. Deep-Sea Res. II, 47, 2281-2298.

Orsi, A. H., Whitworth, T., and Nowlin, W. D. (1995). On the meridional extent and fronts of the Antarctic Circumpolar Current. Deep-Sea Res. I, 42(5), 641-673.

Popova, E. E., Lozano, C. J., Srokosz, M. A., Fasham, M. J. R., Haley, P. J., and Robinson, A. R. (2002). Coupled 3D physical and biological modelling of the mesoscale variability observed in North-East Atlantic in spring 1997: biological processes. Deep-Sea Res. I, 49, 1741-1768.

Quetin, L. B. and Ross, R. M. (1991). Behavioral and physiological characteristics of the Antarctic krill, Euphausia superba. Amer. Zool., 31, 49-63.

Quetin, L. B. and Ross, R. M. (2001). Environmental variability and its impact on the reproductive cycle of Antarctic krill. Am. Zool., 41, 74-89. 
Quetin, L. B. and Ross, R. M. (2003). Episodic recruitment in Antarctic krill Euphausia superba in the Palmer LTER study region. Mar. Ecol. Prog. Ser., 259, 185-200.

Reid, K., Watkins, J. L., Croxall, J. P., and Murphy, E. J. (1999). Krill population dynamics at South Georgia 1991-1997, based on data from predators and nets. Mar. Ecol. Prog. Ser., 177, $103-114$.

Reynolds, R. W., Rayner, N. A., Smith, T. M., Stokes, D. C., and Wang, W. Q. (2002). An improved in situ and satellite SST analysis for climate. J. Clim., 15, 1609-1625.

Ross, R. M. and Quetin, L. B. (1983). Spawning frequency and fecundity of the Antarctic krill Euphausia superba. Mar. Biol., 77, 201-205.

Ross, R. M. and Quetin, L. B. (1989). Energetic cost to develop to the fi rst feeding stage of Euphausia superba Dana and the effect of delays in food availability. J. Exp. Mar. Biol. Ecol., 133, 103-127.

Saunders, P. M., Coward, A. C., and de Cuevas, B. A. (1999). Circulation of the Pacifi c Ocean seen in a global ocean model: Ocean Circulation and Climate Advanced Modelling project (OCCAM). J. Geophys. Res., 104(C8), 18 281-18 299.

Siegel, V. (1986). Untersuchungen zur Biologie des antarktischen Krill, Euphausia superba, im Bereich der Bransfi eld Strasse und angrenzender Gebiete. Mitt. Inst. Seefisch. Hamburg, 38, $1-244$.

Siegel, V. (1988). A concept of seasonal variation of krill (Euphausia superba) distribution and abundance west of the Antarctic Peninsula. In D. Sahrhage, editor, Antarctic Ocean and Resources Variability, pages 219-230. Springer-Verlag.

Siegel, V. (1992). Assessment of the krill (Euphausia superba) spawning stock off the Antarctic Peninsula. Archiv für Fischereiwissenschaft, 41, 101-130.

Siegel, V. (2005). Distribution and population dynamics of Euphausia superba: summary of recent fi ndings. Polar Biol., 29(1), DOI 10.1007/s00300-005-0058-5.

Siegel, V. and Loeb, V. (1994). Length and age at maturity of Antarctic krill. Antarct. Sci., 6, 479-482.

Siegel, V. and Loeb, V. (1995). Recruitment of Antarctic krill Euphausia superba and possible causes for its variability. Marine Ecology Progress Series, 123, 45-56.

Siegel, V., Loeb, V., and Gröger, J. (1998). Krill (Euphausia superba) density, proportional and 
absolute recruitment and biomass in the Elephant Island region (Antarctic Peninsula) during the period 1977 to 1997. Polar Biol., 19, 393-398.

Siegel, V., Kawaguchi, S., Ward, P., Litvinov, F., Sushin, V., Loeb, V., and Watkins, J. (2004). Krill demography and large-scale distribution in the southwest Atlantic during January/February 2000. Deep Sea Res. II, 51, 1253-1273.

Speirs, D. C., Gurney, W. S. C., Heath, M. R., and Wood, S. N. (2005). Modelling the basinscale demography of Calanus finmarchicus in the north-east Atlantic. Fish. Oceanog., 14(5), $333-358$.

Spiridonov, V. A. (1995). Spatial and temporal variability in reproductive timing of Antarctic krill (Euphausia superba Dana). Polar Biol., 15, 161-174.

Steele, M., Zhang, J., Rothrock, D., and Stern, H. (1997). The force balance of sea ice in a numerical model of the Arctic Ocean. J. Geophys. Res., 102(C9), 21 061-21 079.

Steinberg, D. K., Carlson, C. A., Bates, N. R., Johnson, R. J., Michaels, A. F., and Knap, A. H. (2001). Overview of the US JGOFS Bermuda Atlantic Time-series Study (BATS): a decadescale look at ocean biology and biogeochemistry. Deep-Sea Res. II, 48(8-9), 1405-1447.

Stretch, J. J., Hamner, P. P., Hamner, W. M., Michel, W. C., Cook, J., and Sullivan, C. W. (1988). Foraging behaviour of Antarctic krill, Euphausia superba, on sea ice microalgae. Mar. Ecol. Progr. Ser., 44, 131-139.

Taki, K., Hayashi, T., and Naganobu, M. (2005). Characteristics of seasonal variation in diurnal vertical migration and aggregation of Antarctic krill (Euphausia superba) in the Scotia Sea, using Japanese fi shery data. CCAMIR Sci., 12.

Tarling, G. A., Cuzin-Roudy, J., Thorpe, S. E., Shreeve, R. S., Ward, P., and Murphy, E. J. (in press, 2006). Recruitment of Antarctic krill Euphausia superba Dana in the South Georgia region: adult fecundity and the fate of larvae. Mar. Ecol. Prog. Ser.

Thorndike, A. S. and Colony, R. (1982). Sea ice motion in response to geostrophic winds. J. Geophys. Res., 87(C7), 5845-5852.

Thorpe, S. E. (2001). Variability of the southern Antarctic Circumpolar Current in the Scotia Sea and its implications for transport to South Georgia. Ph.D. thesis, Univ. East Anglia, Norwich, UK.

Thorpe, S. E., Heywood, K. J., Brandon, M. A., and Stevens, D. P. (2002). Variability of the 
southern Antarctic Circumpolar Current front north of South Georgia. J. Mar. Sys., 37, 87105.

Thorpe, S. E., Heywood, K. J., Stevens, D. P., and Brandon, M. A. (2004). Tracking passive drifters in a high resolution ocean model: implications for interannual variability of larval krill transport to South Georgia. Deep Sea Res. I, 51, 909-920.

Thorpe, S. E., Stevens, D. P., and Heywood, K. J. (2005). Comparison of two time-variant forced eddy-permitting global ocean circulation models with hydrography of the Scotia Sea. Ocean Modelling, 9, 105-132.

Trathan, P. N., Brierley, A. S., Brandon, M. A., Bone, D. G., Goss, C., Grant, S. A., Murphy, E. J., and Watkins, J. L. (2003). Oceanographic variability and changes in Antarctic krill (Euphausia superba) abundance at South Georgia. Fish. Oceanogr., 12(6), 1-15.

Ward, P., Whitehouse, M., Meredith, M., Murphy, E., Shreeve, R., Korb, R., Watkins, J., Thorpe, S., Woodd-Walker, R., Brierley, A., Cunningham, N., Grant, S., and Bone, D. (2002). The Southern Antarctic Circumpolar Current Front: physical and biological coupling at South Georgia. Deep-Sea Res. I, 49, 2183-2202.

Watkins, J. L., Murray, A. W. A., and Daly, H. I. (1999). Variation in the distribution of Antarctic krill Euphausia superba around South Georgia. Mar. Ecol. Prog. Ser., 188, 149-160.

Watkins, J. L., Hewitt, R., Naganobu, M., and Sushin, V. (2004). The CCAMLR 2000 Survey: a multinational, multi-ship biological oceanography survey of the Atlantic sector of the Southern Ocean. Deep Sea Res. II, 51, 1205-1213.

Webb, D. J. and de Cuevas, B. A. (2003). The region of large sea surface height variability in the Southeast Pacifi c Ocean. J. Phys. Oceanogr., 33, 1044-1056.

Webb, D. J., de Cuevas, B. A., and Coward, A. C. (1998). The fi rst main run of the OCCAM global ocean model. Internal Document 34, Southampton Oceanography Centre.

White, W. B. and Peterson, R. G. (1996). An Antarctic circumpolar wave in surface pressure, wind, temperature and sea-ice extent. Nature, 380, 699-702.

Zakardjian, B. A., Sheng, J. Y., Runge, J. A., McLaren, I., Plourde, S., Thompson, K. R., and Gratton, Y. (2003). Effects of temperature and circulation on the population dynamics of Calanus finmarchicus in the Gulf of St. Lawrence and Scotian Shelf: Study with a coupled, three-dimensional hydrodynamic, stage-based life history model. J. Geophys. Res., 
108(C11), 8016, 10.1029/2002JC001410. 


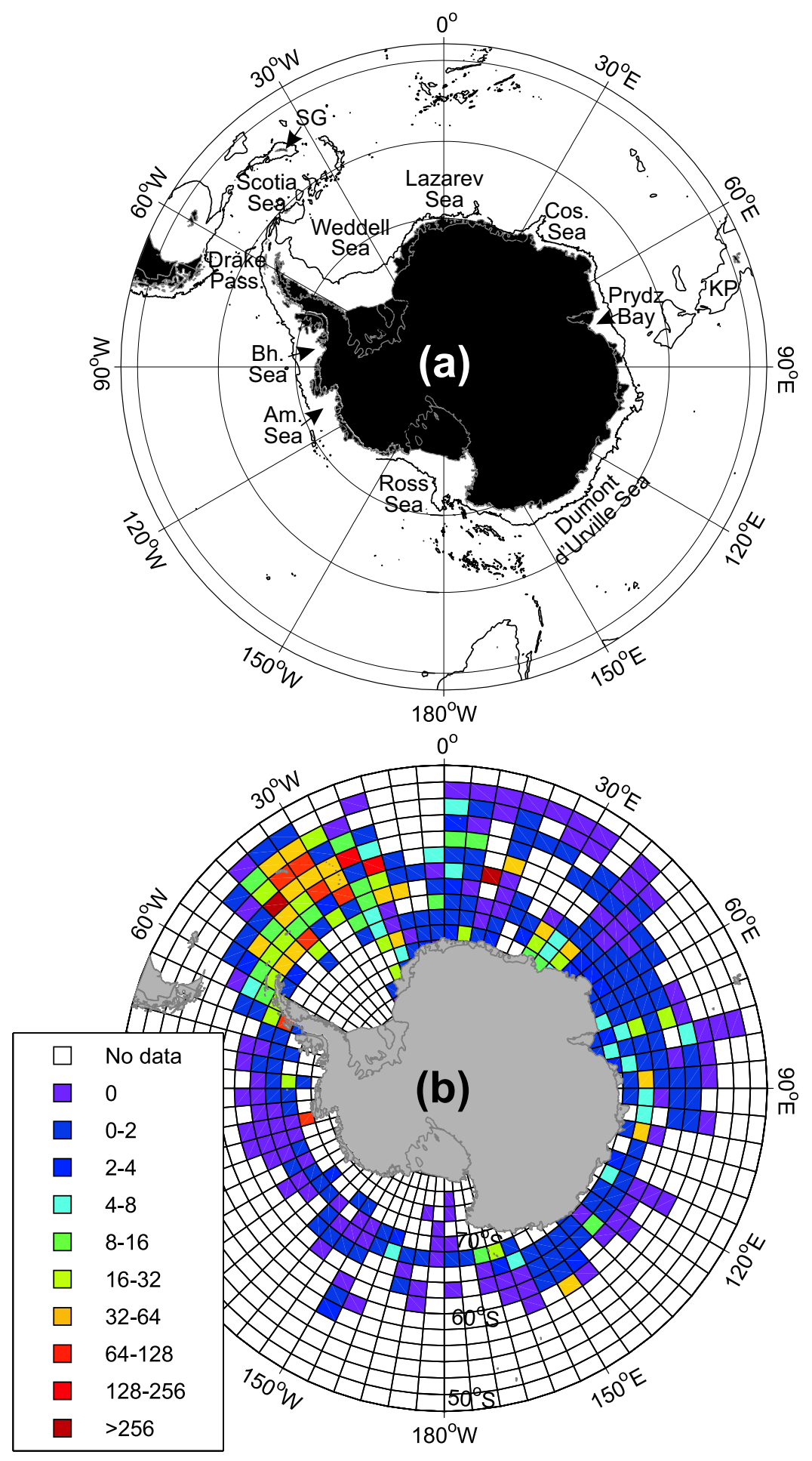

Fig. 1. (a) Location map. The $2000 \mathrm{~m}$ isobath is marked. Am. Sea-Amundsen Sea, Bh. Sea-Bellingshausen Sea, Cos. Sea-Cosmonaut Sea, Drake Pass.-Drake Passage, KP-Kerguelen Plateau, SG-South Georgia. (b) Mean Antarctic krill density (number krill $\mathrm{m}^{-2}$ ), reproduced from Atkinson et al. (2004). 

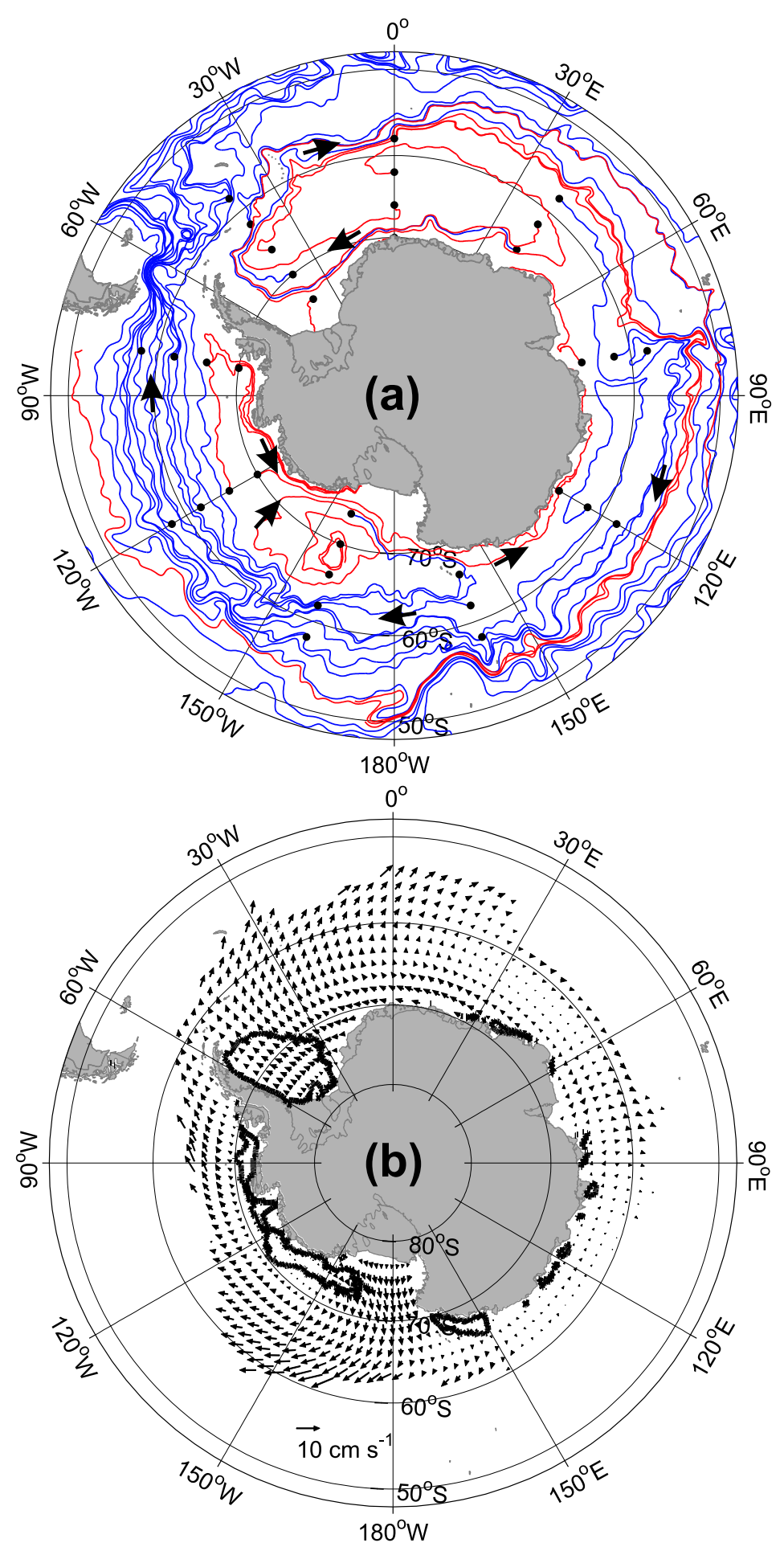

Fig. 2. (a) Horizontal circulation of the Southern Ocean as depicted by passive particles tracked for 10 years in climatological velocity fields (depth-weighted mean of the upper $182 \mathrm{~m}$ ) from OCCAM. Particle release locations are shown by black dots. Particles that exit the study region are coloured blue, those that remain are coloured red. Arrows indicate direction of flow. (b) Annual mean sea ice motion (1978-2003). Mean sea ice extent in January is marked (black line). 


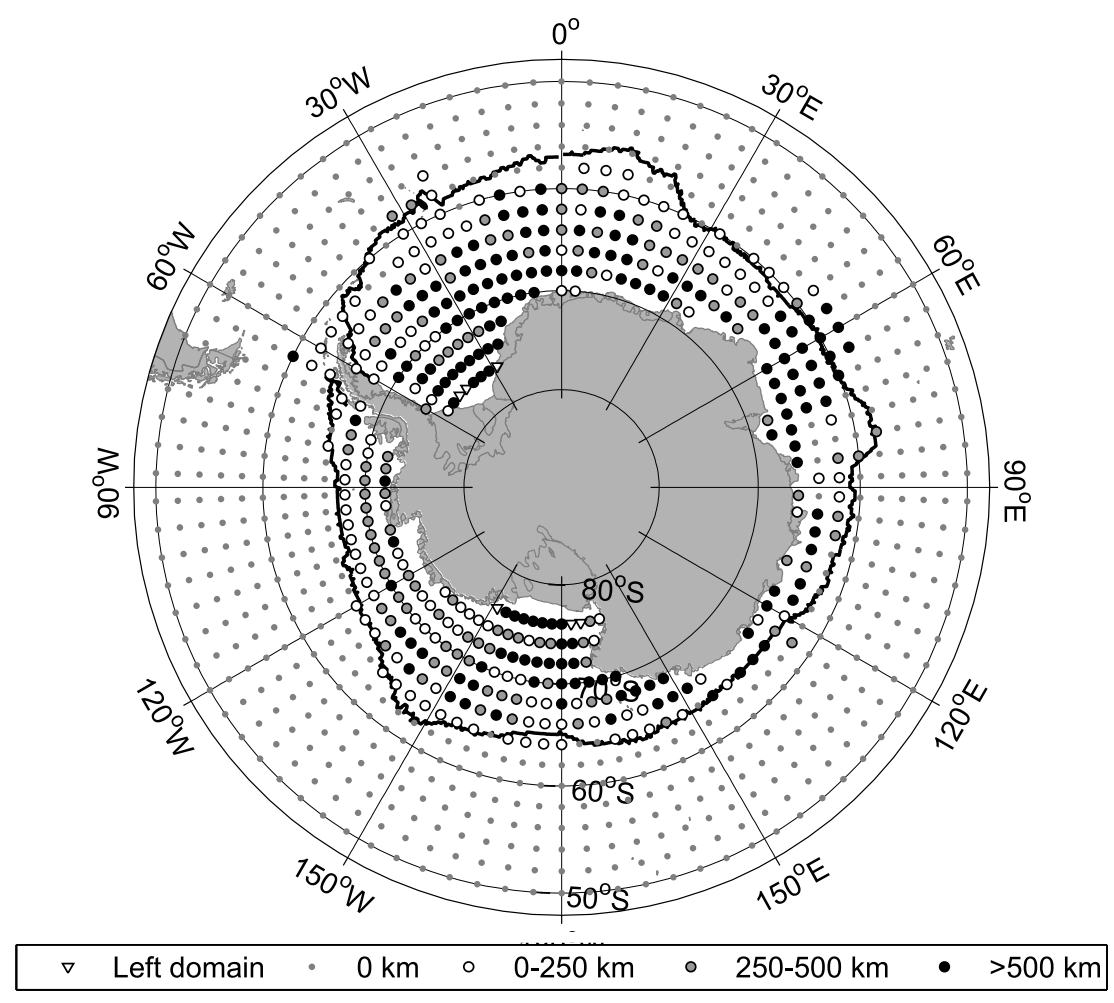

Fig. 3. Particle release location shaded according to distance between end position of the particle following advection in the ocean velocity fields and advection in the combined sea ice/ocean velocity fields for 1 year. The mean September sea ice extent as defined from sea ice motion data is marked (black line). 

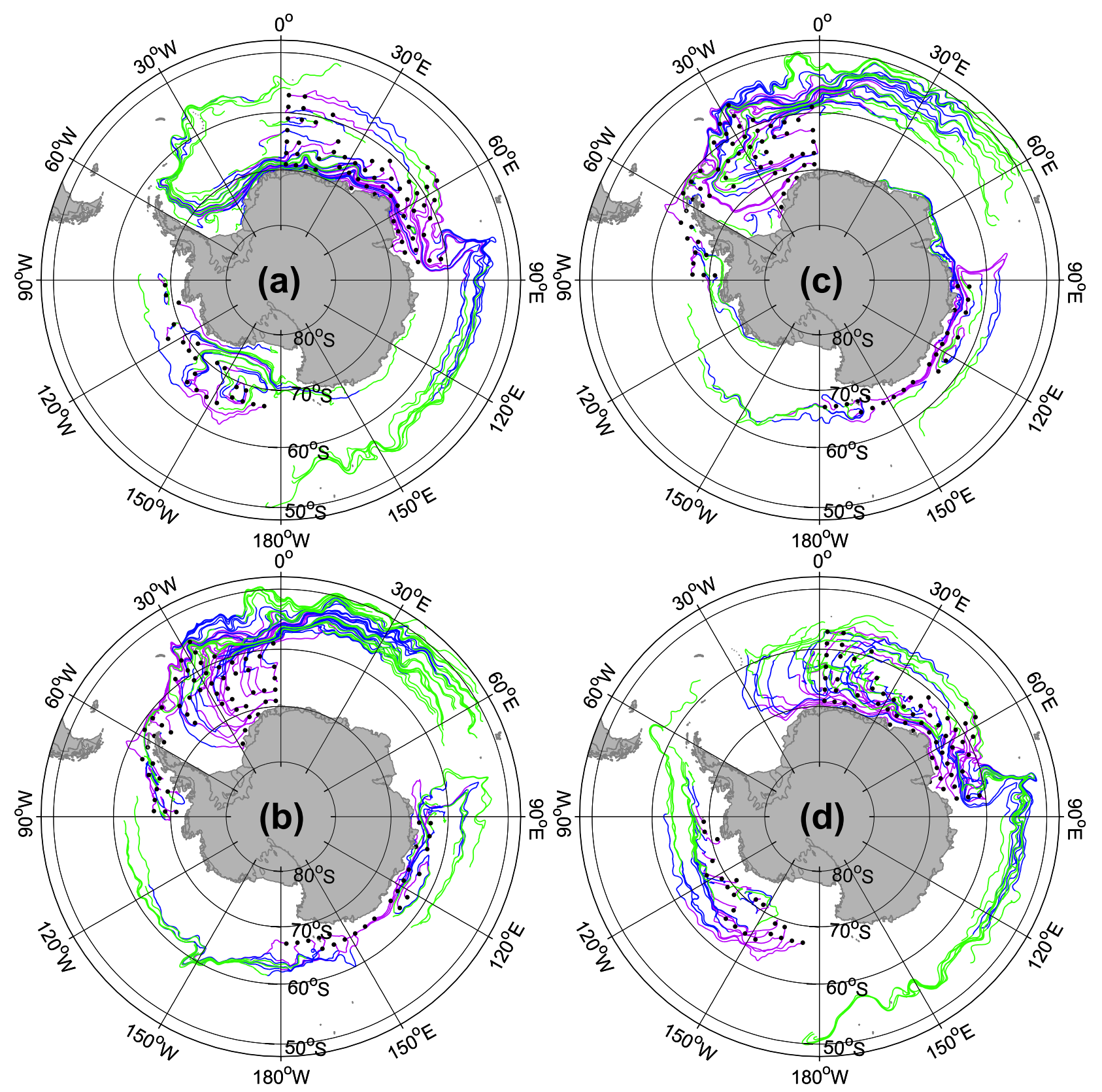

Fig. 4. 3 year trajectories of particles plotted according to release region: $(\mathrm{a}, \mathrm{b}) 90^{\circ} \mathrm{W}-0^{\circ}$ and $90^{\circ} \mathrm{E}-180^{\circ} \mathrm{W}$; (c,d) $0^{\circ}-90^{\circ} \mathrm{E}$ and $90^{\circ} \mathrm{W}-180^{\circ} \mathrm{W}$. (a) and (c) show trajectories derived from the ocean velocity fields, (b) and (d) show those from combined sea ice/ocean velocity fields. Trajectories are coloured according to time: pink-0-1 year; blue $-1-2$ years; green $-2-3$ years. Only those particles that have different trajectories in the two scenarios after one year are plotted. Release sites are marked by black dots. 

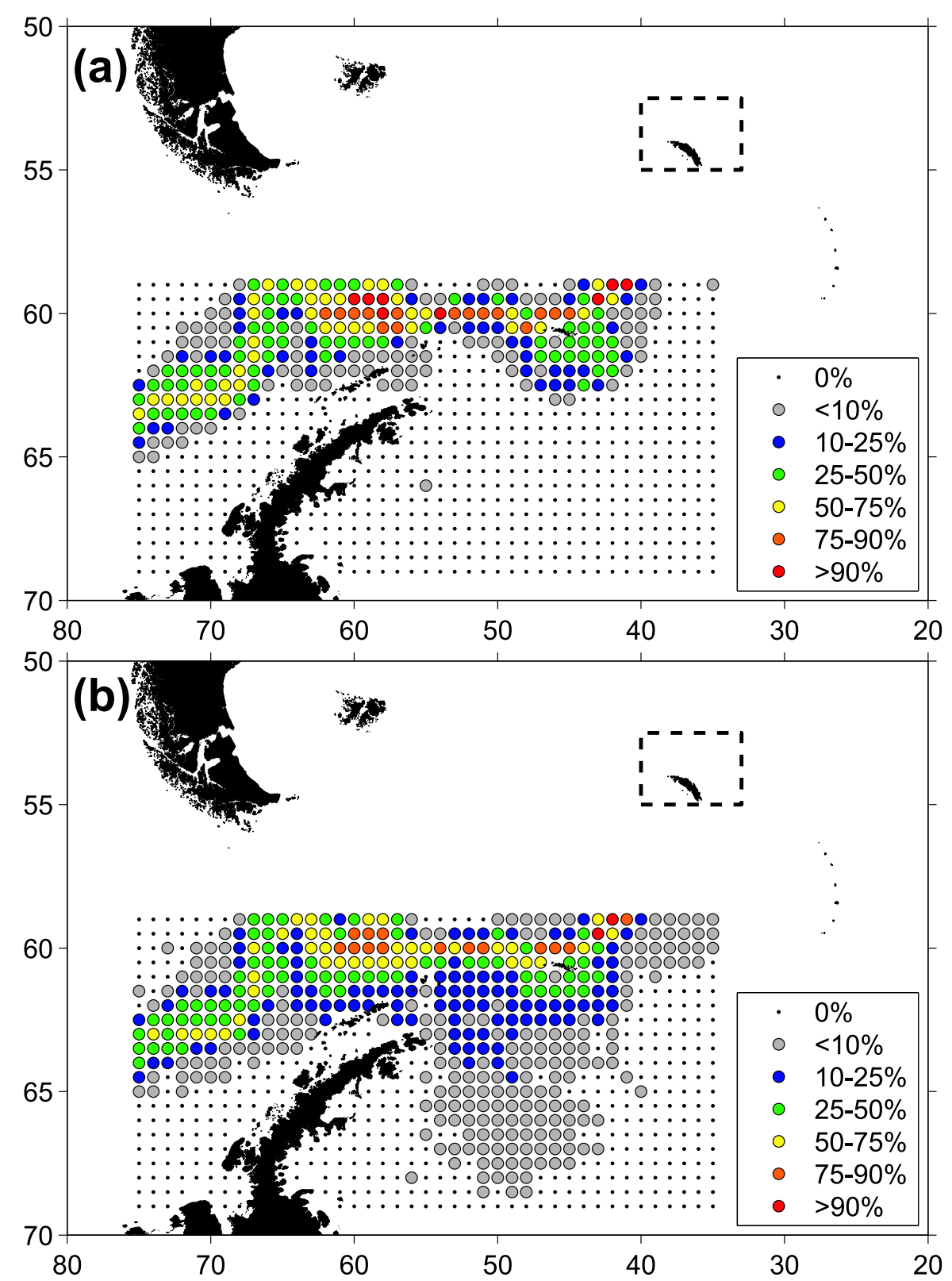

Fig. 5. Distribution maps of the probability of particles released from each release site reaching South Georgia (defined by the particle entering the dashed box around the island) within one year in (a) the ocean only velocity fields, and (b) the combined sea ice/ocean velocity fields. 

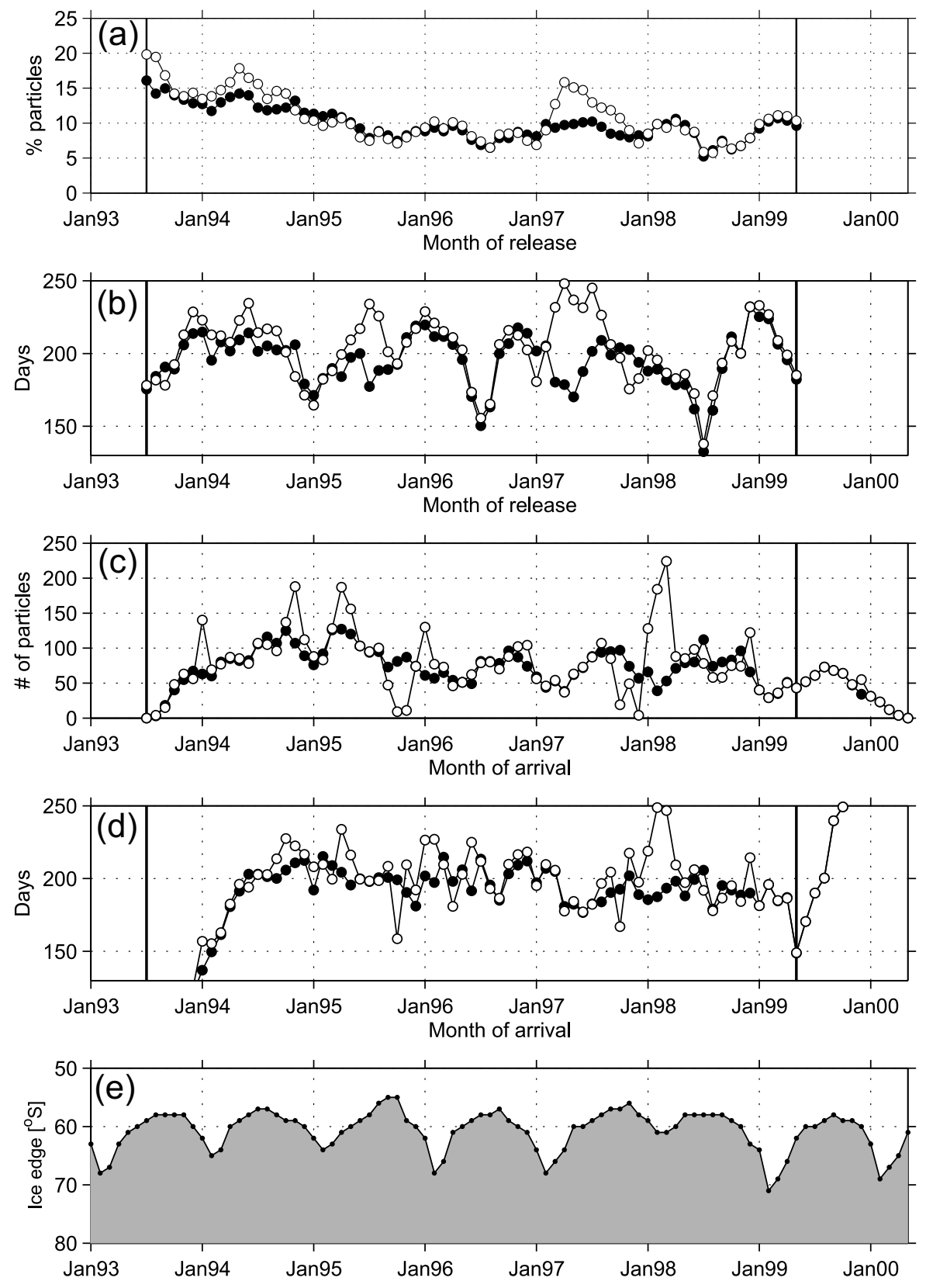

Fig. 6. Temporal variability in transport to South Georgia from ocean only velocity fields (black symbols) and combined sea ice/ocean velocity fields (white symbols). Arrival at South Georgia is determined according to passage into the box marked around South Georgia in Fig. 5. (a) Probability of each monthly release of particles reaching South Georgia within one year. (b) Mean time taken by each monthly release of particles to reach South Georgia. (c) Total number of particles arriving at South Georgia each month within one year of transport. (d) Mean transport time of the monthly influx of particles to South Georgia. (e) Monthly mean sea ice extent at $40^{\circ} \mathrm{W}$ [from the OI.v2 Monthly SST Analysis, Reynolds et al. (2002)]. Vertical lines in (a)-(d) mark the start and end of the particle releases. 


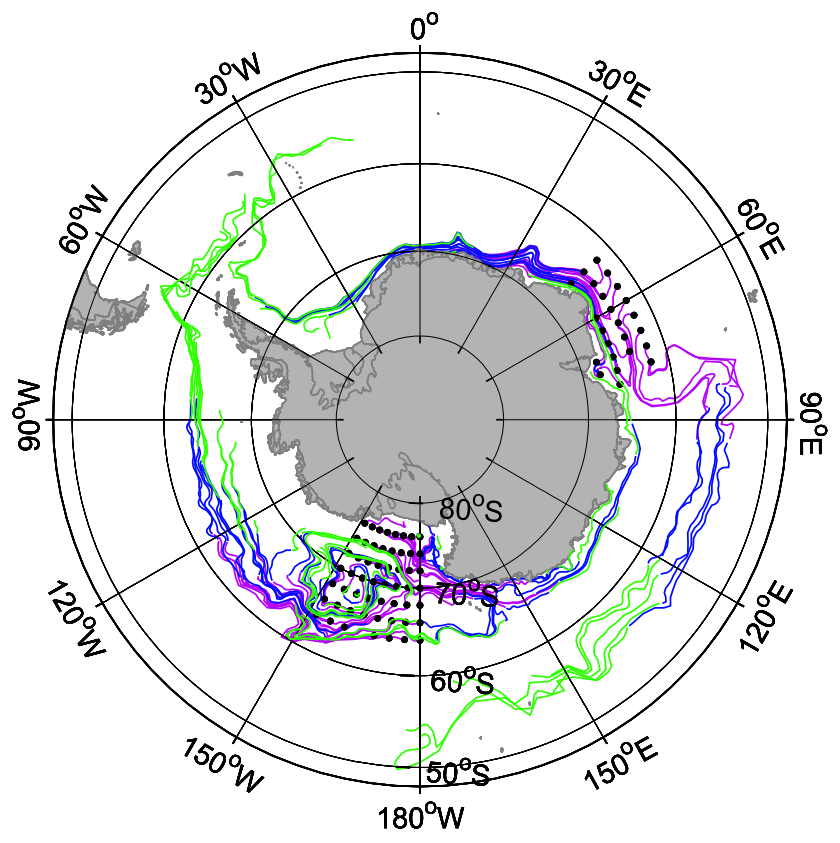

Fig. 7. 3 year trajectories derived from the ocean only velocity fields to illustrate circumpolar source regions to South Georgia. Trajectories are coloured according to Fig. 4. 